\title{
Expression of p-selectin (CD62p) on Platelets as activated marker in preeclampsia .
}

\author{
Alshimaa A . Abdel-Latif* , Fawzia A. EL.Sheshtawy**, Amany A. Bauomy** \\ Obstetrics and Gynecology Department *, Clinical Pathology**, Faculty of Medicine \\ for Girls- Al Azhar University
}

\begin{abstract}
Background : Pre-eclampsia is a medical condition in which hypertension arises in pregnancy (pregnancy-induced hypertension) in association with significant amounts of protein in the urine. Pre-eclampsia may develop from 20 weeks gestation (it is considered early onset before 32 weeks, which is associated with increased morbidity) .Platelets play an important role in the pathophysiologic mechanisms of preeclampsia.
\end{abstract}

Aim: The aim of this work was to study the platelet activation state by flow cytometer analysis of platelet expression of CD62p in patients with preeclampsia.

Methods: This study was conducted on ten cases of mild preeclampsia (group I), their ages range was 22- 36 years and ten cases of severe preeclampsia(group II) their ages range was 20-35 years .Also ten normotensive pregnant women were included as a control group (group III) . The percentage of platelets expression of the CD61, CD62p and MFI were analyzed by the flow- cytometr .

Results: The mean percentage of CD62p expression on platelets and MFI were $67.3 \%$ and 6.5 respectively in mild preeclampsia compared with $3.7 \%$ and 1.5 in normotensive pregnant as control $(\mathrm{p}<0.01$ and $\mathrm{p}<0.015$ respectively $)$. Also the mean percentage of CD62p expression on platelets and MFI were $73.3 \%$ and 2.1 respectively in severe preeclampsia, They showed significant increase when compared with normotensive pregnant as control $(\mathrm{p}<0.01$ and $\mathrm{p}<0.015$ respectively $)$. There were a positive significant correlation between \% of expression of CD 62p on platelets and SBP, DBP, protein in urine, and \% CD61. While a negative significant correlation between \% of expression of CD 62p on platelets and age, platelet count and CD62P MFI was found .

Conclusion : : High levels of platelet glycoprotein CD62p expressions in patients with mild and severe preeclampsia, could be a compensatory mechanism for the preeclampsia induced thrombocytopenia .

Key words : CD 61, CD62p, Flow- Cytometry, preeclampsia

\section{Introduction}

Pre-eclampsia is a medical condition in which hypertension arises in pregnancy (pregnancy-induced hypertension) in association with significant amounts of protein in the urine. Pre-eclampsia refers to a set of symptoms rather than any causative factor, and there are many different causes for the condition. It appears likely that there are substances from the placenta that can cause endothelial dysfunction in the maternal blood vessels of susceptible women .While blood pressure elevation is the most visible sign of the disease, it involves generalized damage to the maternal endothelium, kidneys, and liver, with the release of vasoconstrictive factors being secondary to the original damage (Andrus and Wolfson, 2010 ). 
Pre-eclampsia may develop from 20 weeks gestation (it is considered early onset before 32 weeks, which is associated with increased morbidity). Its progress differs among patients; most cases are diagnosed pre-term. Pre-eclampsia may also occur up to six weeks post-partum. Apart from Caesarean section or induction of labor (and therefore delivery of the placenta), there is no known cure. It is the most common of the dangerous pregnancy complications; it may affect both the mother and the unborn child ( Koopmans et al., 2009).

Thrombocytopenia is another common feature in preeclampsia and platelet counts of less than $100 \times 10 \%$ may occur in up to $50 \%$ of women with severe disease . Platelet life span is also reduced, suggesting that thrombocytopenia is consumptive in nature. In addition some investigators have detected platelet function abnormalities , although clinically important platelet dysfunction is exceeding unusual in preeclampsia ( Lew and, Klonis , 2003) .

The development of thrombocytopenia in patients with preeclampsia is thought to be via increased platelet destruction. The mechanism of platelets destruction is unclear, however some evidence (elevated D- Dimer ) suggested that these patients have an underlying low grade disseminated intravascular coagulation . Elevated platelet associated immunoglobulin is commonly found in this patients, however ,suggesting immune involvement .Early reports suggested that there may be a component of platelets activation because low dose aspirin has been shown to prevent preeclampsia in high risk patients ( Lykke et al.,2009) .

P-selectin, also known as CD62P, Platelet Activation-Dependent Granule to External Membrane Protein( PADGEM) and GMP140 , is an adhesion molecule found in the $\alpha$-granules of platelets and the WeibelPalade bodies of endothelial cells. Upon activation of platelets or endothelial cells,
P-selectin is quickly expressed on the surface membrane, where it mediates both the interaction of activated platelets with leucocytes, and leucocyte rolling on the activated endothelium (Cleator et al ., 2006).

Circulating degranulated platelets rapidly shed surface P-selectin, producing the circulating plasma protein soluble $\mathrm{P}$ selectin (sP-selectin). Although P-selectin is present in both platelets and endothelial cells, several authors have concluded that platelets are the major source of sP-selectin in plasma. Anti-P-selectin antibody has been shown to inhibit thrombus formation, thus providing evidence that P-selectin plays a role in thrombosis( Tedder et al ., 1995 ) .

\section{Subjects and methods}

This study was carried out on 20 pre eclamptic pregnant females admitted to the hospital between September 2009 and July 2010. Ten cases had mild, Ten cases had severe pre eclampsia and 10 uncomplicated pregnant females were included as a comparative group. The cases were selected from the Obstetrics and Gynecology Department of Al-zahraa Hospital Al- Azhar University . Consent was obtained from all women before inclusion in the study. Patient age ranged between ( 20-36 y ) , gestional age ( 32- 39 weeks of gestation). All cases were primigravida with singleton pregnancy. Exclusion criteria included, fetal anomaly, multiple pregnancies, collagen vascular disease, chronic hypertension, diabetes mellitus and gestional diabetes. They diagnosed as cases of preeclampsia according to the criteria proposed by American College of Obstetricians and Gynecologists. Preeclampsia was defined as the presence of hypertension associated with proteinuria after the 20th week of gestation in women known to be normotensive. Mild preeclampsia was defined as a blood pressure of at least $\geq 140$ $\mathrm{mm} \mathrm{Hg}$ (systolic) and/or $90 \mathrm{~mm} \mathrm{Hg}$ (diastolic) on two occasions of up to 4-6h 
apart. The blood pressure was measured on the right arm and with the patient always in the seated position. Proteinuria was defined as urinary excretion of $300 \mathrm{mg}$ or more of protein in $24 \mathrm{~h}$. Severe PET was defined as a diastolic blood pressure $\geq 110 \mathrm{mmHg}$ or severe proteinuria ( urinary excretion $5 \mathrm{~g}$ per 24 hours ). Intrauterine growth restriction (IUGR) was defined by the presence of ultrasographic signs ( biparitial diameter below the $10^{\text {th }}$ centile and abdominal circumference below the $5^{\text {th }}$ percentile according to the Normogram of Camphell and Thoms( 1977) .

Gestional age determined from last normal menstrual period and confirmed by fetal biometry at the routine ultrasound scane at 16-20 weeks or first trimester measurement of crown rump length .

Fetal assessment was done by ultrasound, fetal cardiotography and umbilical artery Doppler.

$5 \mathrm{ml}$ of peripheral venous blood were withdrawn ; under aseptic condition from antecubital vein with a minimum of stasis, from each subject and control. They were divided as follows :

- $2 \mathrm{ml}$ in $\mathrm{BD}$ vacutainers with anticoagulant sodium citrate 1: 9, for flow cytometric analysis . The analysis was performed within 4-6 hours from the venous puncture.

$-1 \mathrm{ml}$ in EDTA for complete blood picture. $-2 \mathrm{ml}$ in tube without anticoagulant for liver and kidney function.

\section{CD61 FITC and CD62P- PE detection was done by flow cytometr model BECKMAN COULTER MACHINE :}

Preparation of surface CD 61 and CD62p analysis

All Kits supplied by( BECKMAN COULTER) ( Catalog No B.P177-13276 Marseille Cedex 9 France)

The citrated blood samples were centrifuged at $2000 \mathrm{rp}$ for 10 minutes at room temperature and the platelet-rich plasma (PRP) obtained . The plasma supernatant was taken for analysis.

Platelet immunostaining was performed as PRP was prepared. The number of platelets was adjusted to $20000 / \mu 1$ using phosphate buffered saline. Aliquots of PRP were mixed 1:8 with fluorescein isothiocyanate (FITC) conjugated anti-CD61 and phycoerythrin (PE)conjugated anti-CD62p and incubated for 30 minutes at room temperature or in refregerator .Thereafter the tube is mixed and immediately analysed by flow cytometry. Ten thousand cells were measured by flow cytometry and analysed by Cell Quest Software .The platelet population evaluated and, Platelets were gated and then statistical analysis by Cell Quest Software was done.

\section{Statistical Analysis}

Data was analyzed by Microsoft Office 2003 (Excel) and Statistical Package for Social Science (SPSS) version 10.

Parametric data was expressed as mean \pm $\mathrm{SD}$, and non parametric data was expressed as number and percentage of the total.

Measuring the mutual correspondence between two values was done using the Spearman correlation coefficient. 


\section{Results}

Table (1) : Clinical characteristics of the pregnant women and infant of the studied groups.

\begin{tabular}{|c|c|c|c|c|}
\hline Clinical data . & $\begin{array}{l}\text { G I }(n=10) \\
\text { mean } \pm \text { SD }\end{array}$ & $\begin{array}{l}\mathrm{GII}(\mathrm{n}=10) \\
\text { mean } \pm \mathrm{SD}\end{array}$ & $\begin{array}{c}\mathrm{GIII}(\mathrm{n}=10) \\
\text { mean } \pm \mathrm{SD}\end{array}$ & $\mathrm{P}$ Value \\
\hline Maternal age (Years) & $29.6 \pm 5.4$ & $27.4 \pm 4.2$ & $27.4 \pm 4.8$ & 0.508 (NS) \\
\hline $\mathrm{SBP}(\mathrm{mmHg})$ & $146 \pm 5.2$ & $153 \pm 4.8$ & $116 \pm 5$ & $<0.001(\mathrm{HS})$ \\
\hline $\mathrm{DBP}(\mathrm{mmHg})$ & $100 \pm 0.0$ & $110 \pm 0.0$ & $77 \pm 4.8$ & $<0.001$ (HS) \\
\hline Gestional age at sampling (Weeks) & $\begin{array}{l}33.17 \pm 0.66 \\
(32.4-34.5)\end{array}$ & $\begin{array}{l}32.8 \pm 0.96 \\
(32.0-34.6)\end{array}$ & $\begin{array}{l}33.8 \pm 1.2 \\
(32.6-36.9)\end{array}$ & 0.098 (NS) \\
\hline Gestional age at delivery (weeks) & $36.0 \pm 060$ & $34.3 \pm 1.08$ & $38.3 \pm 0.9$ & $<0.001$ (HS) \\
\hline C. S $[\mathrm{n}(\%)]$ & $4(40 \%)$ & $9(90 \%)$ & $1(10 \%)$ & $<0.001(\mathrm{HS})$ \\
\hline $\begin{array}{l}\text { Small for gestional age } 10 \text { percentile [ } \mathrm{n} \\
(\%)]\end{array}$ & $0(0 \%)$ & $4(40 \%)$ & $0(0 \%)$ & $<0.001(\mathrm{HS})$ \\
\hline Fetal birth weight (g) & $2890 \pm 230$ & $2100 \pm 103$ & $3033 \pm 315$ & $<0.001(\mathrm{HS})$ \\
\hline
\end{tabular}

There were high significant increase in SBP, DBP in both groups I and II in comparison with the control group (III). While there were high significant decrease in gestional age at delivery, fetal birth weight in both groups I and II in comparison with the control group (III). Also there was high significant increase in the percentage of cesarean section in severe preeclampsia in comparison mild preeclampsia and control group.

$P$ value $>0.05$ is considered non-significant $(N S)$.

$P$ value $\leq 0.05$ is considered significant $(S)$.

$P$ value $\leq 0.01$ is considered highly significant ( $H S$ ).

Group $I=$ mild peeclampsia, Group $I I=$ severe preeclampsia, Group $I I I=$ control group . 
Alshimaa Abdel-Latif ....et al

Table (2): Comparison between mild and severe preeclampsia as regard protien in urine .

\begin{tabular}{|c||c|c||c|c|}
\hline & \multicolumn{4}{|c|}{ Groups } \\
\cline { 2 - 5 } & Group I & Group II & \multicolumn{2}{c|}{ T-test } \\
\cline { 2 - 6 } & Mean \pm SD & Mean \pm SD & P-value \\
\hline $\begin{array}{c}\text { Protien in } \\
\text { urine mg/ } \\
24 h\end{array}$ & $684.5 \pm 151.3$ & $1763.0 \pm 301.7$ & -10.105 & $\begin{array}{c}<0.001 \\
\text { (HS) }\end{array}$ \\
\hline \hline
\end{tabular}

Group I = mild peeclampsia, Group II, = severe preeclampsia

There was high significant increase in protein in urine in severe preeclampsia in comparison with mild preeclampsia.

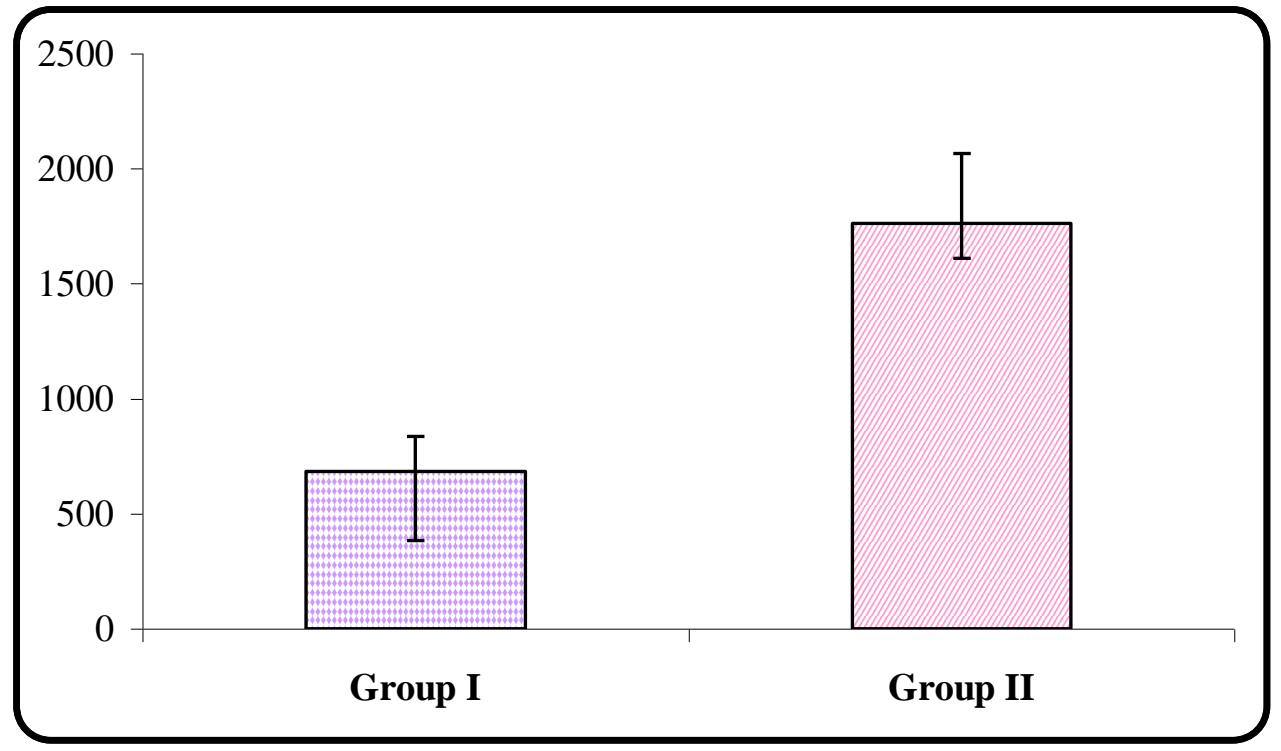

Figure (1): Mean values of protein in urine /24h in mild and severe preeclampsia 

Table (3): Comparison between mild ( group I) and severe ( group II) preeclampsia with normotensive pregnant women ( group III) as regard platelets count .

\begin{tabular}{|c|c|c|c|c|c|c|}
\hline \multirow{3}{*}{ Group I } & \multirow{2}{*}{\multicolumn{2}{|c|}{ Range( / cm) }} & \multirow{2}{*}{\multicolumn{2}{|c|}{ Mean \pm SD }} & \multicolumn{2}{|c|}{ ANOVA } \\
\hline & & & & & $\overline{f f}$ & P-value \\
\hline & \multicolumn{2}{|c|}{$170.0-220.0$} & $193.9 \pm$ & 14.19 & \multirow{3}{*}{80.179} & \multirow{3}{*}{$\begin{array}{c}<0.001 \\
(\mathrm{HS})\end{array}$} \\
\hline Group II & \multicolumn{2}{|c|}{$80.0-150.0$} & 106.3 & 23.6 & & \\
\hline Group III & \multicolumn{2}{|c|}{$222.0-356.0$} & \multicolumn{2}{|c|}{$288.7 \pm 48.5$} & & \\
\hline \multicolumn{7}{|c|}{ Tukey's Test } \\
\hline \multicolumn{2}{|c|}{ Group I\& Group II } & \multicolumn{2}{|c|}{ Group I\& Group III } & \multicolumn{3}{|c|}{ Group II\& Group III } \\
\hline \multicolumn{2}{|c|}{$<0.001(\mathrm{HS})$} & \multicolumn{2}{|c|}{$<0.001(\mathrm{HS})$} & & \multicolumn{2}{|c|}{$<0.001(\mathrm{HS})$} \\
\hline
\end{tabular}

There was high significant decrease in platelets count in both group I and II in comparison with the control group. Also there was high significant decrease in platelets count in severe preeclampsia in comparison with mild preeclampsia.

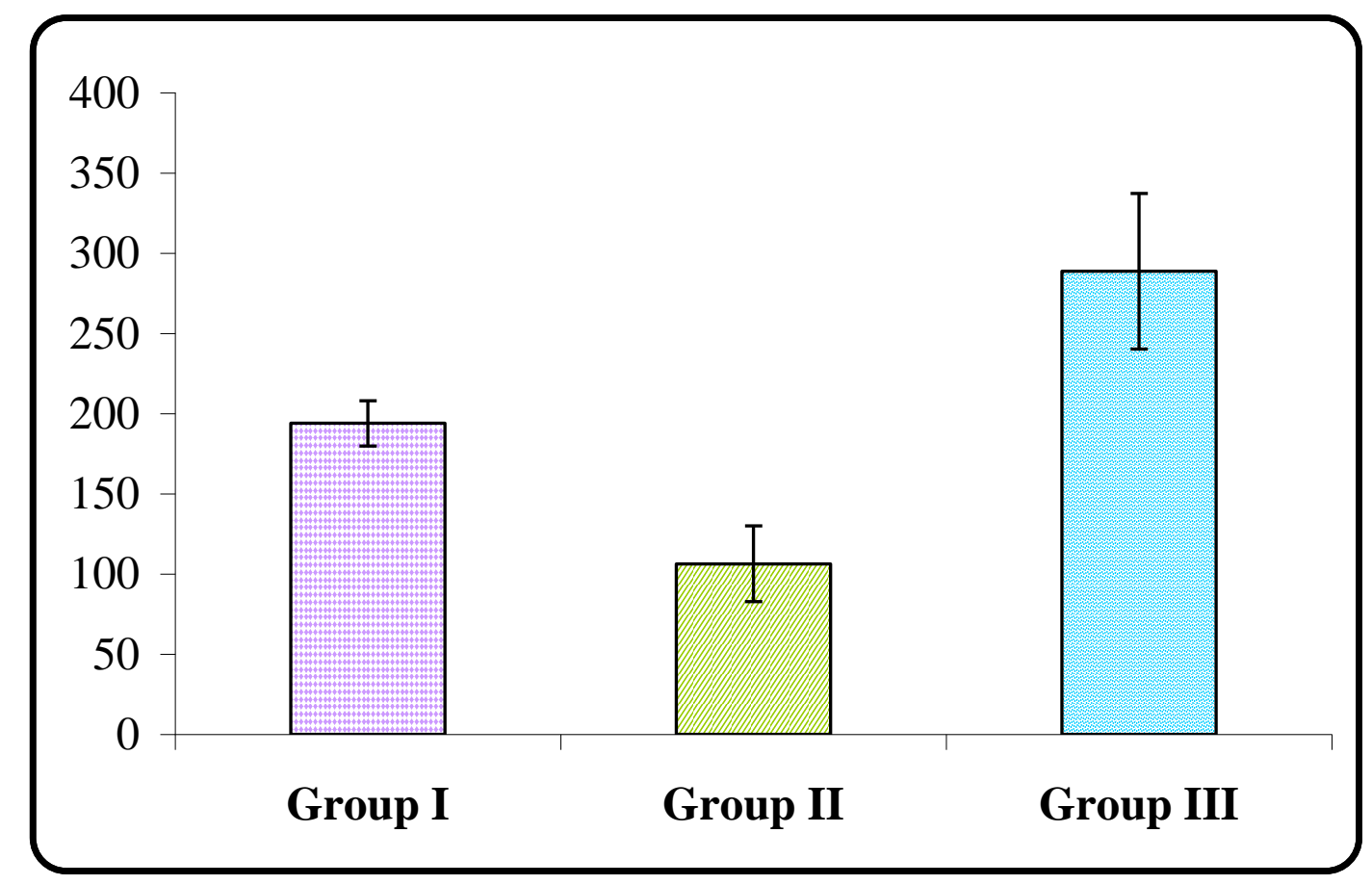

Figure (2): Mean platelets count/cmm in the three studied groups . 
Table (4): Comparison between mild and severe preeclampsia with normotensive pregnant women as regard \% of expression of CD62p on platelets

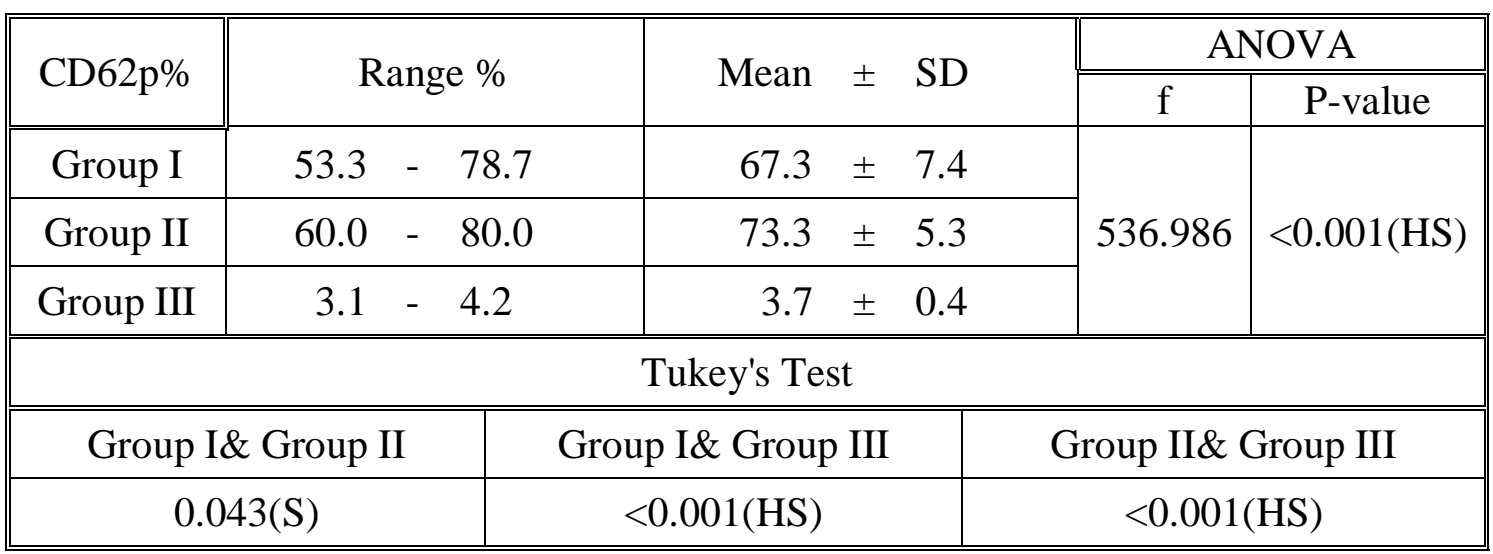

There was high significant increase in \% of expression of CD 62p on platelets in both group I and group II in comparison with group III. Also high significant increased \% of expression of CD62p in severe preeclampsia was detected in comparison with mild preeclampsia.

Group $I=$ mild peeclampsia, Group $I I=$ severe preeclampsia, Group $I I I=$ normotesive pregnant women ( control group).

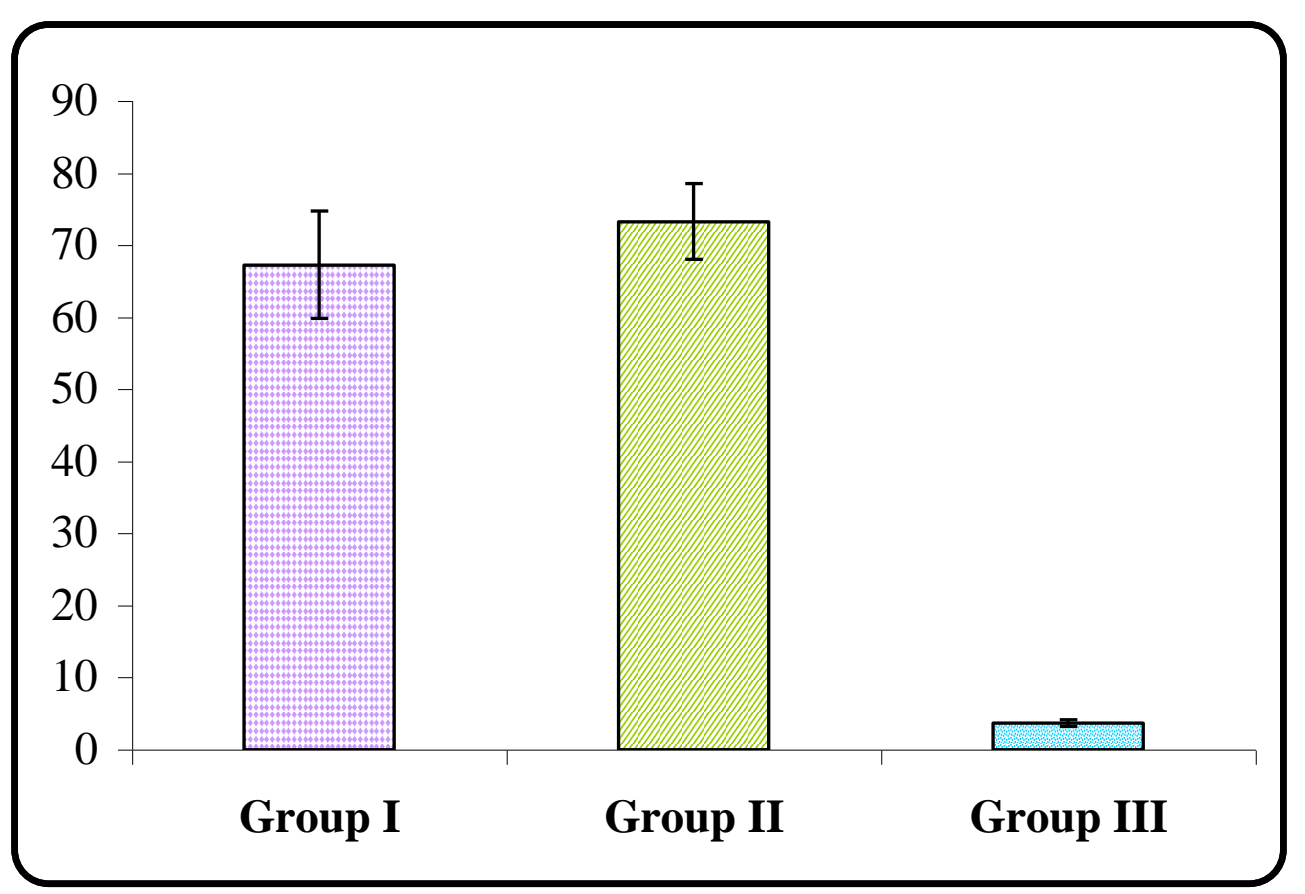

Figure (3): Mean values of \% of expression of CD62p on platelets in the three studied groups. 
Table ( 5) : Comparison between mild and severe preeclampsia with normotensive pregnant women as regard MFI of expression of CD62p on platelets ..

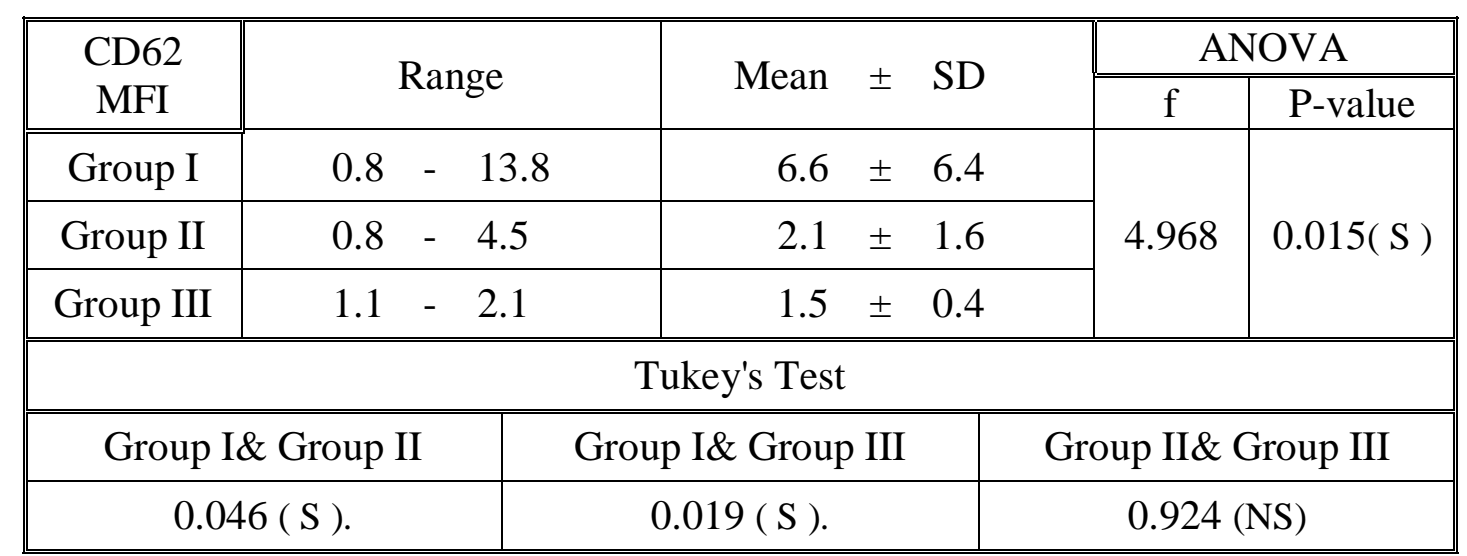

There was significant increase MFI of expression of CD62p on platelets in mild preeclampsia (group I) in comparison with both severe preeclampsia (group II) and group III (control group). On the other hand there was no significant difference between group II and group III .

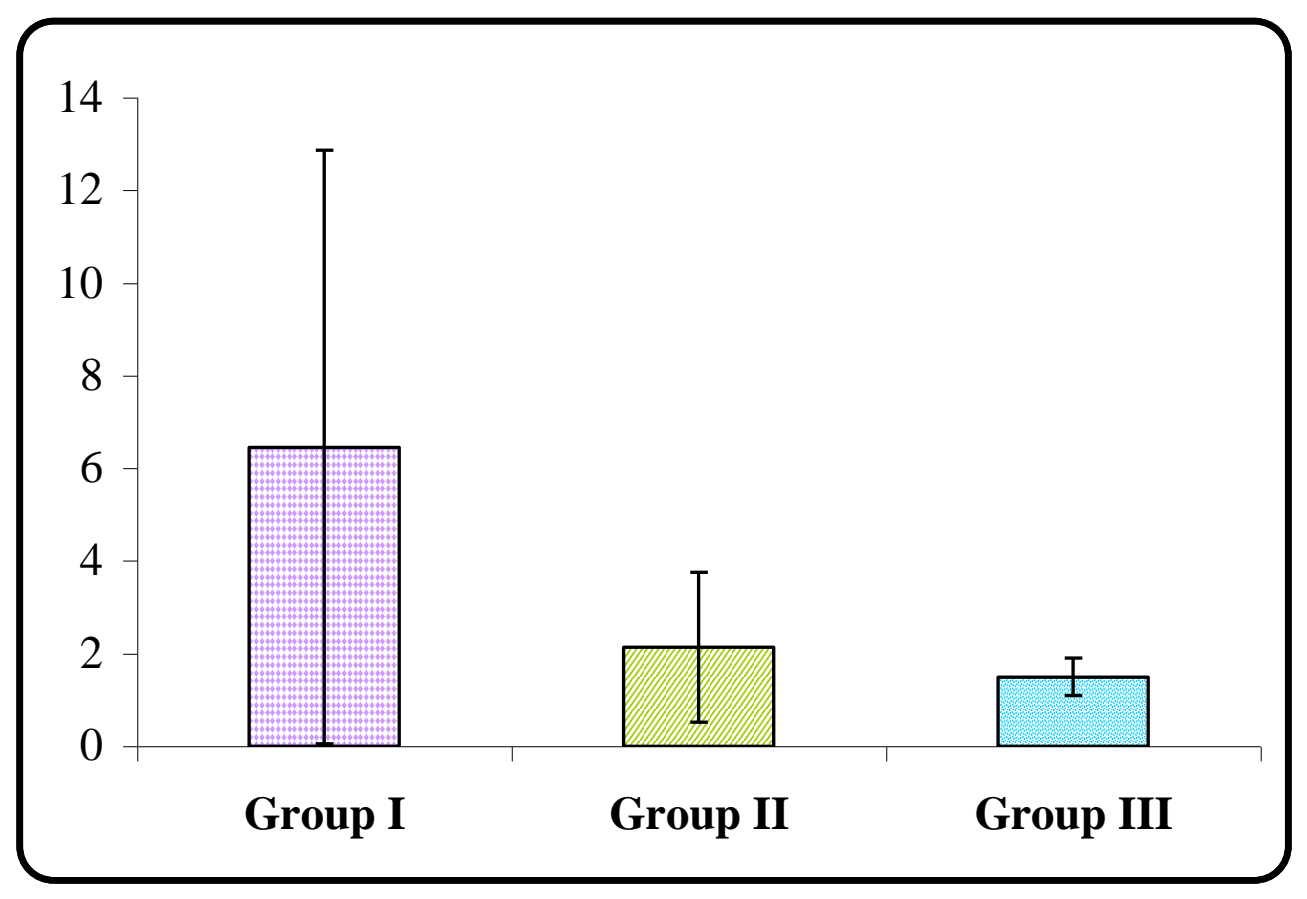

Figure (4): Mean values of MFI of CD62p expression on platelets in the three studied groups. 
1:

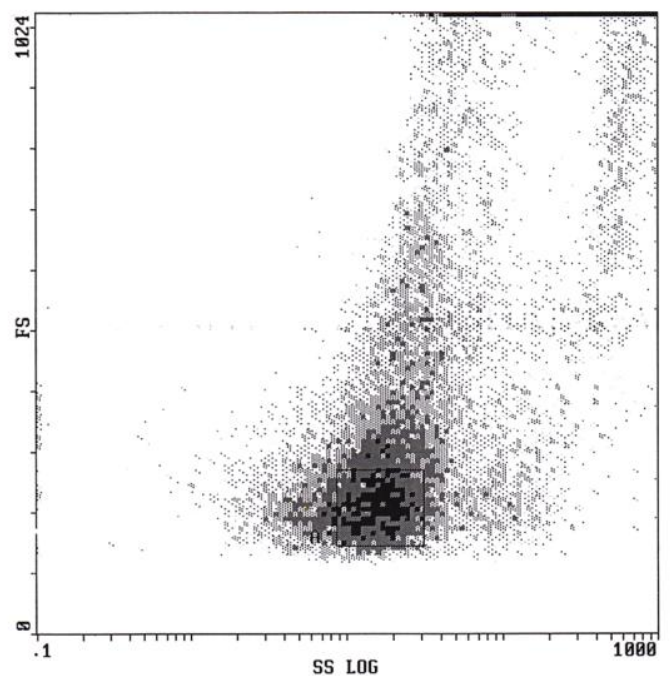

3: A

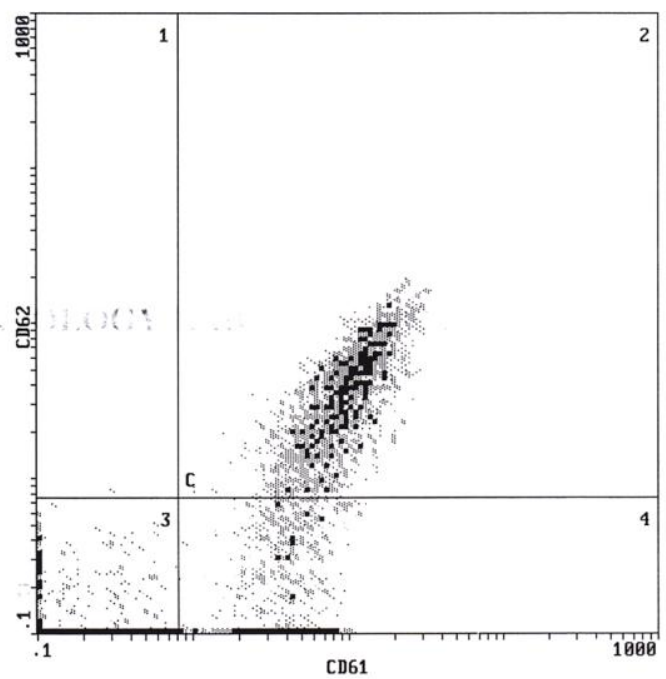

Stats: Normalized, Listgating: Disabled

\begin{tabular}{clrrr} 
Hist & Region ID & $\%$ & MnI X & MnI Y \\
\hline $\mathbf{1}$ & A A & 21.6 & 17.6 & 205.5 \\
$\mathbf{3}$ & C1 C & 0.03 & 0.312 & 0.855 \\
& C2 C & 77.8 & 11.3 & 4.48 \\
& C3 C & 26.6 & 0.269 & 0.139 \\
& C4 C & 65.6 & 4.60 & 0.261
\end{tabular}

Figure (5): shows coexpression of CD62p \% and CD $61 \%$ on platelets in a patient with severe preeclampsia .

Table (6) Correlation between \% of expression of CD 62p on platelets and all other studied parameters in mild and severe preeclampsia.

\begin{tabular}{|c|c|c|}
\hline \multirow{2}{*}{ Age } & \multicolumn{2}{|c|}{ CD62p\% } \\
\cline { 2 - 3 } & $\mathbf{r}$ & P-value \\
\hline SBP & -0.463 & $0.040 *(\mathrm{~S})$ \\
\hline DBP & 0.501 & $0.032 *(\mathrm{~S})$ \\
\hline WBC & 0.484 & $0.039 *(\mathrm{~S})$ \\
\hline Hb & 0.222 & $0.347(\mathrm{NS})$ \\
\hline Pletelet & 0.325 & $0.161(\mathrm{NS})$ \\
\hline Protien in urine & -0.382 & $0.047 *(\mathrm{~S})$ \\
\hline creatinin & 0.469 & $0.042 *(\mathrm{~S})$ \\
\hline CD61\% & 0.247 & $0.293(\mathrm{NS})$ \\
\hline CD61 MFI & 0.618 & $0.004 *(\mathrm{~S})$ \\
\hline CD62 MFI & 0.049 & $0.838(\mathrm{NS})$ \\
\hline
\end{tabular}

There were a positive significant correlation between \% of expression of $C D 62 p$ on platelets and $S B P$, $D B P$, protein in urine, and \% CD61. While a negative significant correlation between \% of expression of CD 62 on platelets and age, platelet count and CD62P MFI was found. 


\section{Discussion:}

Pre eclamrpsia, a pregnancy specific disorder characterized clinically by new onset hypertension and protinuria after 20 weeks of gestation is most frequently encountered medical complication during pregnancy affecting $3.5 \%$ of pregnant women world wide .

Preeclampsia is a leading cause of maternal mortality with estimates of > 60,000 maternal deaths / year ( Rana and Karumanchi, 2009 ) .

In the present study there were no significant differences in maternal age, body mass index and gestional age at blood sampling between the women with preeclampsia and the normotensive controls. The patient with preeclampsia had significant elevations in blood pressure both systolic and diastolic $(\mathrm{P}<0.001$ and $\mathrm{P}<$ 0.001 ) respectively( table 1 ) .

There were, however, no significant difference between the study groups and control group as regard age, $\mathrm{Hb}$ and liver function .

Proteinuria is defined as $300 \mathrm{mg}$ or more of protein in a 24-hour urine sample ( Knight et al ., 2010 ). All patients had proteinuria which was more in severe preeclamptic group and this difference was highly statistically significant $(\mathrm{P}<0.001)$.

In this study the gestional age at delivery was significantly lower in cases with preeclampsia when compared with the control group $(\mathrm{p}<0.001)$.

The mean length of gestation at delivery in women with severe pregnancy induced hypertension( PIT) was $34.3 \pm 1.08$ (32.836 weeks ) compared with $36.02 \pm 0.6$ ( 34.7 - 37 weeks ) in mild cases of PIT and $38.3 \pm 0.9(37.3-39)$ in control group .

Preeclampsia may lead to intrauterine growth retardation and prematurity related to uteroplacental insufficiency, which may result in fetal and neonatal complications (e.g. sepsis, hypoxia, or acidosis). The effects of preeclampsia on the fetus depend mainly on the time of onset, duration, and severity of preeclampsia (Lykke et al ., 2009) .

The theory of abnormal placental implantation or reduced trophoblast invasion continues to link preeclampsia and intrauterine growth restriction (IUGR) as pregnancy disorders with a common pathogenesis ( Villar et al ., 2006 ) .

In the present study birth weights were significantly lower in cases of preeclampsia compared with the control group $\mathrm{p}<$ 0.001 .Four out of ten neonates of severe PIT were complicated with IUGR .

In this study significantly higher percentage of cesarean section was shown in the severe PIT $(90 \%) \quad \mathrm{p}<0.00$ compared with ( $40 \%$ ) in mild PIT and ( $10 \%$ ) in the control group.

Excessive platelet activation is associated with endothelial dysfunction, thrombosis in microcirculation, end organ degenerative necrosis, placental infarction and IUGR

( Holthe et al ., 2004).

Preeclampsia has been associated with increased platelets activation detected before disease onset. Platelets are involved in hemostasis and also directly initiate an inflammatory response of the blood vessel wall, inappropriate activation of platelets may be involved in pathogenesis in preeclampsia by promoting coagulation and thrombosis, and also as a mediator of inflammation (Boehlen,et al., 2000). The cause of thrombocytopenia is thought to be secondary to endothelial damage causing a low grade coagulopathy. Some authors have proposed an immune mechanism for thrombocytopenia, and others, have proposed activation of platelets ( Andrus and Wolfson ,2010). 
The present study showed lower platelets count ( thrombocytopenia ) in preeclamptic patients when compared with control group - This difference was statistically highly significant $(\mathrm{P}<0.001)$. Also platelet count was significantly lower in cases with severe preeclampsia versus mild cases ( $\mathrm{p}$ $<0.001)$.

Platelet-surface glycoprotiens (GPs) are involved in adhesion and aggregation processes. Changes such as increases or decreases in the number of binding sites could therefore affect platelet function ( Ruggeri , 2003).

The percentage of expression of CD 62p on platelets was higher in mild and severe preeclampsia compared with control group ( normal pregnancy) and these differences were statistically highly significant $(\mathrm{p}<$ 0.001 ) for both mild and severe cases .

There was a positive significant correlation between the percentage of expression of CD62p with both SBP and DBP, suggesting that the level of platelet activation could be proportional to systolic and diastolic blood pressure.

The initiating event in preeclampsia is generally regarded to be placental ischemia, followed by the release of a number of vasoactive factors that alter the endothelial function and platelet function ( Mutter and Karumanchi ,2008 ).

Also there was a positive significant correlation between percentage of expression of $\quad$ CD62p on platelets and the amount of protein in urine/ $24 \mathrm{~h}$. Women with preeclampsia have markedly decreased renal blood flow and glomerular filtration rates . Some consider glomerular capillary endothelial swelling that is accompanied by deposits of fibrinogen degradation products within and under the endothelial cells as pathognomonic of the disease ( Hladunewich et al ., 2007).

It was interesting to notice a significant negative correlation between the level of expression of CD62p and the platelets count in preeclampsia. This finding could reveal that the increased platelet activation for maintaining hemostasis was a compensatory mechanism for the preeclampsia associated thrombocytopenia . Other correlation studies suggested that, patients with preeclampsia with a many risk factors had a lower platelet count.

In conclusion: In preeclampsia , thrombocytopenia was associated with increased platelet activation which was evidenced by the high level of the percentage of expression of $p-$ selectin ( CD62p) . This could be a compensatory mechanism to maintain hemostais .

\section{References}

1- Rana WS , and Karumanchi SA . (2009). Preeclampsia: The Role of Angiogenic Factors in Its Pathogenesis , Physiology, 24 ( 3 ) :147158.

2- Xiong Y, Liebermann DA and Tront JS. (2009). "Gadd45a stress signaling regulates sFlt-1 expression in preeclampsia". Journal of Cellular Physiology, 220 (3): 632- 639.

3-Koopmans CM, Van Pampus MG, Groen H, Aarnoudse JG, Van Den Berg PP and Mol BW. (2009). "Accuracy of serum uric acid as a predictive test for maternal complications in pre-eclampsia: bivariate meta-analysis and decision analysis.". European journal of obstetrics, gynecology, and reproductive biology , 146 (1): 8-14.

4- Cleator JH, Zhu WQ, Vaughan DE and Hamm HE . ( 2006). "Differential regulation of endothelial exocytosis of P-selectin and von Willebrand factor by protease-activated receptors and cAMP.". Blood ,107 (7): 2736-44. 6- Knight M, Kurinczuk JJ, Spark $P$ and Brocklehurst P. (2010). Extreme obesity in pregnancy in the United Kingdom. Obstet Gynecol., 115(5):989-97.

7- Tedder TF, Steeber DA, Chen A, Engel P. (1995). The selectins: vascular adhesion molecules. FASEB J., 9: 866- 873. 8-Villar J, Carroli G, Wojdyla D, Abalos E, Giordano D and Ba'aqeel H. (2006). Preeclampsia, gestational hypertension and intrauterine growth restriction, related independent conditions. Am J Obstet Gynecol ., 194 : 921-931

9 - Holthe MR, Staff AC and Berge LN . (2004) : Different levels of platelet activation 
in preeclamptic, normotensive pregnant, and nonpregnant women. Am J

Obstet Gynecol ., 190(4):1128-1134

10- Ruggeri ZM., (2003 ) : Von Willebrand factor, platelets and endothelial cell interactions. J Thromb Haemost., 1: 1335-1342.

11- Compbell S and Thoms A (1977). Ultrasound measurement of the fetal head to abdomen circumference ratio in the assessment of growth retardation , $\mathrm{Br} \mathrm{J}$ obstet gynaecal ., 89: 165-174.

12- Lew M and Klonis E (2003 ). Emergency management of eclampsia and severe preeclampsia. Emerg Med Fremantle .,15(4):3618.

13-Sibai BM ., (2002):Chronic hypertension in pregnancy. .Obstet Gynecol ., 100:369-377.

14- Boehlen, F, Hohlfeld, P and Extermann, P,( 2000). Platelet count at term pregnancy: a reappraisal of the threshold. Obstet Gynecol ., 95:29.

15- Andrus SS and Wolfson AB. (2010). Postpartum preeclampsia occurring after resolution of antepartum preeclampsia. $J$ Emerg Med., 38(2):168-70

16- Thadhani RI, Johnson RJ and Karumanchi SA . ( 2005 ). Hypertension during pregnancy: a disorder begging for pathophysiological support. Hypertension , 46: 1250-1251

17- Germain AM, Romanik MC, Guerra I, Solari S, Reyes MS, Johnson RJ, Price K, Karumanchi SA and Valdes G ( 2007). Endothelial dysfunction: a link among preeclampsia, recurrent pregnancy loss, and future cardiovascular events? Hypertension, 49: 90-95

18- Mutter W and Karumanchi A S. ( 2008 ). Molecular mechanisms of preeclampsia.

Microvasc Res., 75(1):1-8

19 -Lykke JA, Paidas MJ and Langhoff-Roos J.( 2009 ) . Recurring complications in second pregnancy. Obstet Gynecol .,113(6):1217-1224 20-Hladunewich M, Karumanchi SA and Lafayette R. ( 2007). Pathophysiology of the clinical manifestations of preeclampsia. Clin $J$ Am Soc Nephrol., 2(3):543-9. 


\section{تعبير سي دي 62 ب على الصفائح الدموية كاعلامة نثاط للصفائح الدموية فى تسمم الحمل كاعل}

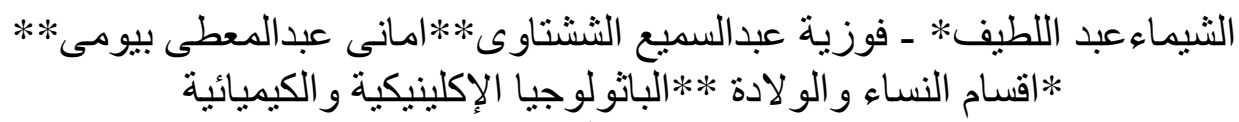

جامعة الأزهر

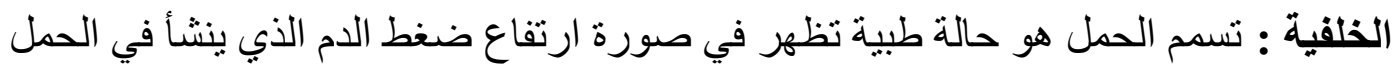

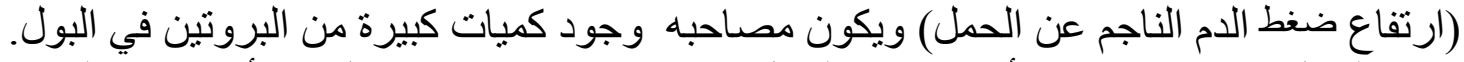

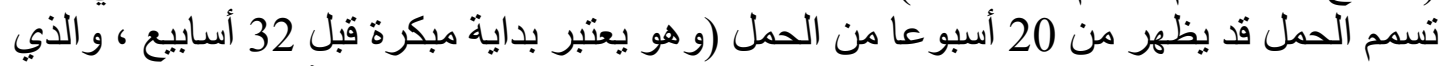

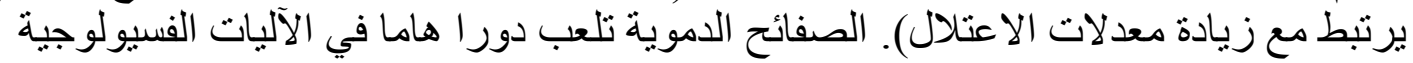

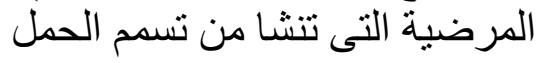

الهدف : كان الهدف من هذه الدراسة هو تحديد نشاط الصفائح الدموية الأساسية عن طريقة تحاليل

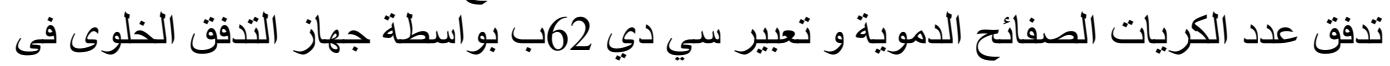

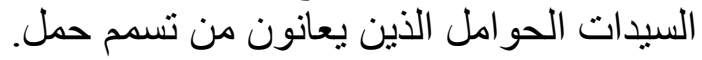

الأساليب: أجريت هذه الدر اسة على عشرة حالات من السيدات الذين يعانون من تسم حمل خفيف

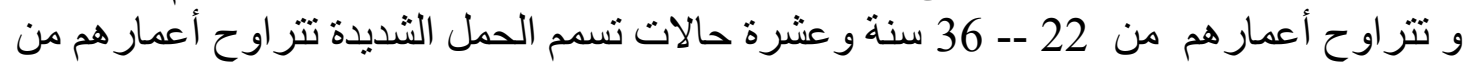

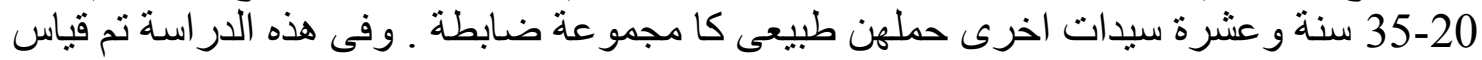

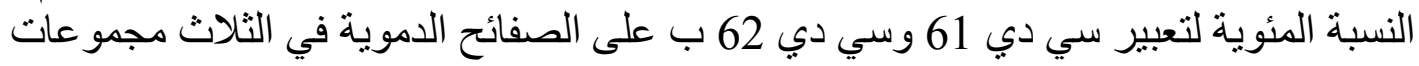

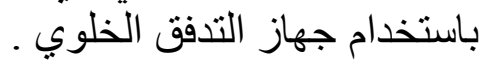

النتأْج : كانت النسبة المئوية التعبير لوجود سي دي 62 ب ب على الصفائح الدموية ومتوسط شندة

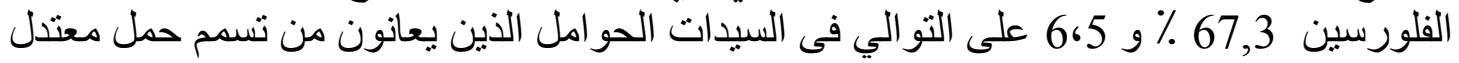

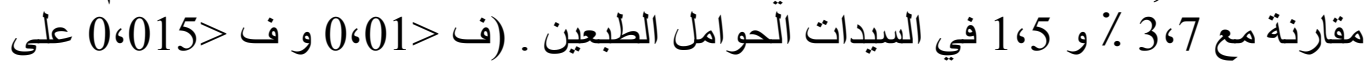

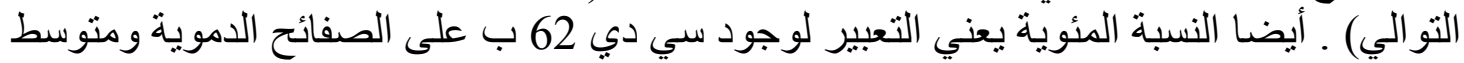

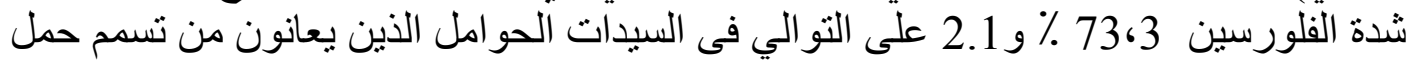

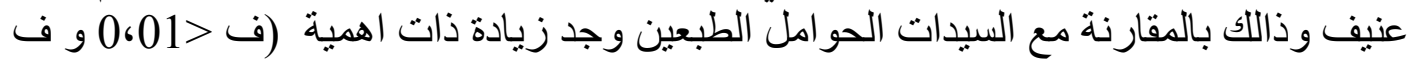

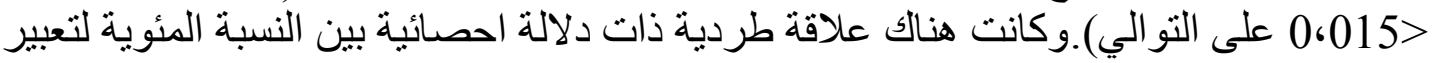

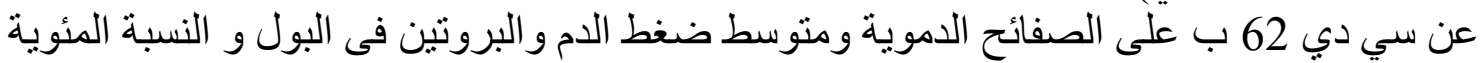

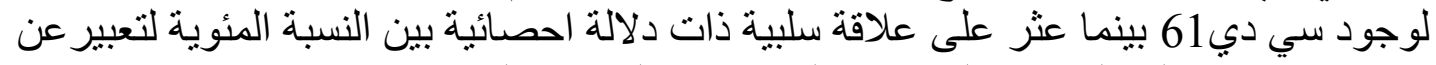
سي دي 62 ب على الصفائح الدموية و السن و على عدد الصفائح الدموية و سي دي 62 بـ ب متوسط شدة الفلورسين على الصفائح الدموية الصفي الصية

و الخلاصة : ارتفاع معدلات الجليكوبروتين الصفائحى سي دي 62 ب على الصفائح الدموية

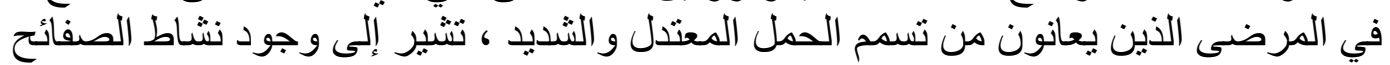

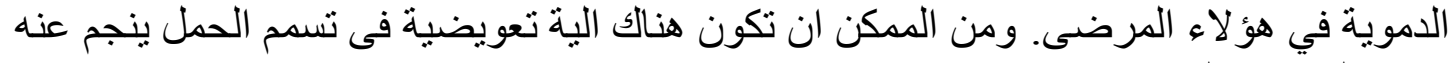
نقص الصفائح الدموية. 